\title{
Diporate Pollen Grains of Poaceae Species: High Pollen Resolution for Reconstruction of Grasslands Vegetation
}

\author{
Radaeski JN*, Cunha DJ and Bauermann SG \\ Laboratório de Palinologia da Universidade Luterana do Brasil-ULBRA, Universidade \\ Luterana do Brazil, Brazil
}

\section{Research Article}

Volume 2 Issue 3

Received Date: February 012017

Published Date: March 29, 2017

*Corresponding author: Radaeski JN, Laboratório de Palinologia da Universidade Luterana do Brasil-ULBRA, Universidade Luterana do Brazil, Brazil, E-mail: jefferson.radaeski@gmail.com

\section{Abstract}

This study documents the relationship between the modern diporate Poaceae pollen grains and fossil diporate Poaceae pollen grains of Quaternary in the southern Brazil. Pollen grains were analyzed to know the number of the apertures of the pollen grains of 95 Poaceae species of Rio Grande do Sul region. These 95 species, five showed diporate aperture and we present the morphological descriptions of pollen grains. In the sedimentary samples of Águas Claras region, seven diporate Poaceae pollen grains were identified in all the profile. Diporate Poaceae pollen grains were absent in the basal ages (10.974-2.000 years BP) and increased in frequency from the Late Holocene (2.000 years BP to the present). The comparison between modern-fossil pollen allowed to identify three palynomorphs in the specie level (Dichantelium sabulorum) also indicating the metabolism type (C3) and two pollen grains indicated the vegetation type (grasslands). C3 diporate Poaceae species that reflect the occurrence of humid climate have increased the concentration since 2.000 years BP in the pollen record. Furthermore, the humid climate increased progressively until the current climate in the region of Águas Claras. The palynomorphs identified can provide important paleoecological information on the dynamics of Poaceae vegetation in the past.

Keywords: Pollen analysis; Pollen morphology; Late Holocene; Southern Brazil

\section{Introduction}

Poaceae pollen grains are easily identified by their monoporate and spheroidal shape morphology. However, the uniform pollen morphology is shown by many Poaceae species and poses problems in the separation of groups among species of the family based on pollen morphology [1,2]. Thus, the identification of the Poaceae pollen grains in the pollen records usually is limited at the family level. Many studies in the last decades have focused on improving the identification of groups of Poaceae pollen grains demonstrating satisfactory progress. These studies were focused on the morphometric analysis on light microscopy [3-21] or observation of the surfaces of the pollen grains under scanning electron microscopy [22-42]. The use of scanning electron microscopy is difficult for studies of pollen fossil records. Thus, the light microscopy is more appropriate for the analysis of many palynomorphs.

Diporate pollen grains occur in species of many botanical families (eg. Cannabaceae, Moraceae, Acanthaceae, Urticaceae), but the pores in the pollen grains of these species are located in the equatorial region 


\section{Open Access Journal of Agricultural Research}

and are distant $[17,43,44]$. The pores of the diporate pollen grains of the family Poaceae (Figure 1) are located in the polar region and are very close $[5,45,46]$.

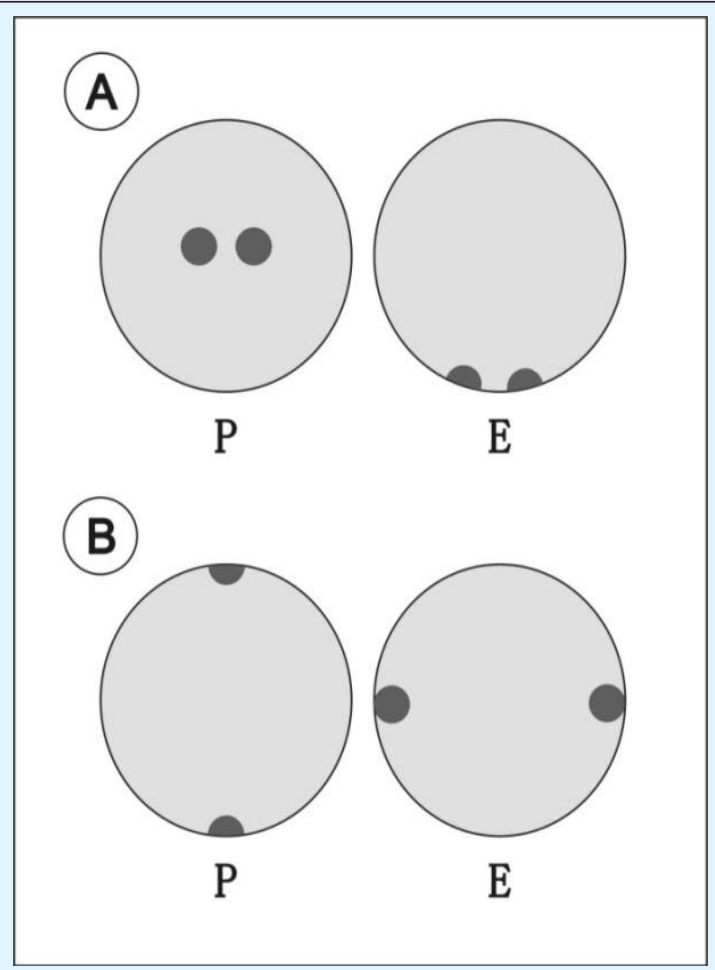

Figure 1: Representation of pollen grains in the family Poaceae (A) and diporate pollen grains of species of the others families (B).

Although the majority of Poaceae species present pollen morphology with monoporate and spheroidal pollen grains, some species present diporate or more apertures [5,21,29,45-49]. The increase in the number of apertures is related to reproduction by apomixis and in cases that sexual reproduction is not viable [45]. As only some species present this pollen morphology (diporate), these may be indicative that these species are easily identified in pollen records. In this sense, as an attempt to refine the taxonomic resolution of Poaceae pollen through diporates Poaceae pollen grains, the present work has the following objectives: (1) Identify in 95 Poaceae species the species that have diporate pollen morphology and select these pollen grains to describe their morphologies modern pollen grains; (2) Identify diporate Poaceae pollen grains in Quaternary sediment showed the ages in which they occurred in the past - fossil pollen grains; (3) Establish relationship modern pollen - fossil pollen of diporate Poaceae de Poaceae seeking higher pollen taxonomic resolution.

\section{Materials and Methods}

\section{Modern Pollen Grains}

Pollen material of 95 Poaceae species was collected in the plants in the field and also in plants deposited in the ICN herbarium. All plants collected in the field were pressed, dehydrated and deposited in the the "Herbário do Museu de Ciências Naturais" from the Universidade Luterana do Brasil (MCNU/HERULBRA). The pollen material of all species was chemically processed according to the acetolysis methodology proposed by Erdtman (1952) [50] and slides created for each sample using glycerinated jelly were deposited in the Laboratório de Palinologia da ULBRA. Six species showed diporate pollen grains from the 95 samples analyzed (Table 1). These six species were selected for pollen description according to the terminology proposed by Barth and Melhem (1988) [51] and Punt et al. (2007) [52] and measuring 25 grains of pollen. In the pollen grains was measured the diameter of the pollen grain (D), pore diameter $(\mathrm{P})$ and annulus diameter $(\mathrm{A})$.

\begin{tabular}{|c|c|c|}
\hline \multirow{2}{*}{ Species } & \multicolumn{2}{|c|}{ Aperture } \\
\cline { 2 - 3 } & $\begin{array}{c}\text { Monop } \\
\text { orate }\end{array}$ & $\begin{array}{c}\text { Dipo } \\
\text { rate }\end{array}$ \\
\hline Agenium villosum (Nees) Pilg. & $\mathrm{x}$ & \\
\hline Agrostis sp. L. & $\mathrm{x}$ & \\
\hline Aira elegantissima Schur & $\mathrm{x}$ & \\
\hline $\begin{array}{c}\text { Amphibromus quadridentulus (Döll) } \\
\text { Swallen }\end{array}$ & $\mathrm{x}$ & \\
\hline Andropogon cf. lindmanii Hack. & $\mathrm{x}$ & \\
\hline Andropogon lateralis Nees & $\mathrm{x}$ & \\
\hline Aristida sp. L. & $\mathrm{x}$ & \\
\hline $\begin{array}{c}\text { Arundinella hispida (Humb. \& } \\
\text { Bonpl. ex Willd.) Kuntze }\end{array}$ & $\mathrm{x}$ & \\
\hline Avena sativa L. & $\mathrm{x}$ & \\
\hline Avena strigosa Schreb. & $\mathrm{x}$ & \\
\hline Axonopus sp. P.Beauv. & $\mathrm{x}$ & \\
\hline $\begin{array}{c}\text { Bothriochloa laguroides (DC.) } \\
\text { Herter }\end{array}$ & $\mathrm{x}$ & \\
\hline $\begin{array}{c}\text { Bouteloua megapotamica (Spreng.) } \\
\text { Kuntze }\end{array}$ & $\mathrm{x}$ & \\
\hline Briza minor L. & $\mathrm{x}$ & \\
\hline Bromus catharticus Vahl & $\mathrm{x}$ & \\
\hline $\begin{array}{c}\text { Calamagrostis viridiflavescens } \\
\text { (Poir.) Steud. }\end{array}$ & $\mathrm{x}$ & \\
\hline Catapodium rigidum (L.) C.E.Hubb. & $\mathrm{x}$ & \\
\hline $\begin{array}{c}\text { Cenchrus clandestinus (Hochst. ex } \\
\text { Chiov.) Morrone }\end{array}$ & $\mathrm{x}$ & \\
\hline Cenchrus equinatus L. & $\mathrm{x}$ & \\
\hline Chascolytrum subaristatum (Lam.) & $\mathrm{x}$ & \\
\hline
\end{tabular}




\section{Open Access Journal of Agricultural Research}

\begin{tabular}{|c|c|c|}
\hline Desv. & & \\
\hline Chloris canterae Arechav. & $\mathrm{x}$ & \\
\hline Chusquea juergensii Hack. & $\mathrm{x}$ & \\
\hline $\begin{array}{c}\text { Colanthelia cingulata (McClure \& } \\
\text { L.B.Sm.) McClure }\end{array}$ & $\mathrm{x}$ & \\
\hline Cynodon dactylon (L.) Pers. & $\mathrm{x}$ & \\
\hline Dactylis glomerata L. & $\mathrm{x}$ & \\
\hline $\begin{array}{c}\text { Danthonia secundiflora subsp. } \\
\text { secundiflora J.Presl }\end{array}$ & $\mathrm{x}$ & \\
\hline $\begin{array}{l}\text { Dichanthelium sabulorum (Lam.) } \\
\text { Gould \& C.A. Clark var. sabulorum }\end{array}$ & $\mathrm{x}$ & $\mathrm{x}$ \\
\hline Digitaria ciliares (Retz.) Koeler & $\mathrm{x}$ & $\mathrm{x}$ \\
\hline Diplachne fusca (L.) P. Beauv. & $\mathrm{x}$ & \\
\hline $\begin{array}{c}\text { Echinochloa polystachya (Kunth) } \\
\text { Hitchc. }\end{array}$ & $\mathrm{x}$ & $\mathrm{x}$ \\
\hline Eleusine tristachya (Lam.) Lam. & $\mathrm{x}$ & \\
\hline Elionurus candidus (Trin.) Hack. & $\mathrm{x}$ & \\
\hline Eragrostis airoides & $\mathrm{x}$ & \\
\hline $\begin{array}{c}\text { Eragrostis bahiensis Schrad. ex } \\
\text { Schult. }\end{array}$ & $\mathrm{x}$ & \\
\hline Eragrostis neesii Trin. & $\mathrm{x}$ & \\
\hline Eragrostis plana & $\mathrm{x}$ & \\
\hline Eriochloa montevidensis Griseb. & $\mathrm{x}$ & \\
\hline Eriochrysis cayennensis P. Beauv. & $\mathrm{x}$ & \\
\hline Eustachys distichophylla (Lag.) Nees & $\mathrm{x}$ & \\
\hline Festuca fimbriata Nees & $\mathrm{x}$ & \\
\hline Glyceria multiflora Steud. & $\mathrm{x}$ & \\
\hline Guadua trinii (Nees) Nees ex Rupr. & $\mathrm{x}$ & \\
\hline $\begin{array}{l}\text { Gymnopogon spicatus (Spreng.) } \\
\text { Kuntze }\end{array}$ & $\mathrm{x}$ & \\
\hline Holcus lanatus L. & $\mathrm{x}$ & \\
\hline Hordeum stenostachys Godr. & $\mathrm{x}$ & \\
\hline $\begin{array}{c}\text { Hymenachne grumosa (Nees) } \\
\text { Zuloaga }\end{array}$ & $\mathrm{x}$ & \\
\hline $\begin{array}{l}\text { Ichnanthus pallens (Sw.) Munro ex } \\
\text { Benth. }\end{array}$ & $\mathrm{x}$ & \\
\hline Imperata brasiliensis Trin. & $\mathrm{x}$ & \\
\hline Ischaemum minus J.Presl & $\mathrm{x}$ & \\
\hline $\begin{array}{c}\text { Jarava megapotamica (Spreng.) } \\
\text { Peñail }\end{array}$ & $\mathrm{x}$ & \\
\hline $\begin{array}{c}\text { Jarava plumosa (Spreng.) S.W.L. } \\
\text { Jacobs \& J. Everett }\end{array}$ & $\mathrm{x}$ & \\
\hline Leersia sp. Sol. ex Sw. & $\mathrm{x}$ & \\
\hline Lithachne pauciflora (Sw.) P.Beauv. & $\mathrm{x}$ & \\
\hline Lolium multiflorum L. & $\mathrm{x}$ & \\
\hline Lolium temulentum L. & $\mathrm{x}$ & \\
\hline Luziola peruviana Juss. ex J.F.Gmel. & $\mathrm{x}$ & \\
\hline Melica sp. L. & $\mathrm{x}$ & \\
\hline Merostachys multiramea Hack. & $\mathrm{x}$ & \\
\hline Microchloa indica (L.f.) P. Beauv. & $\mathrm{x}$ & \\
\hline
\end{tabular}

\begin{tabular}{|c|c|c|}
\hline Muhlenbergia schreberi J.F.Gmel. & $\mathrm{x}$ & \\
\hline $\begin{array}{c}\text { Nassella melanosperma (J. Presl) } \\
\text { Barkworth }\end{array}$ & $\mathrm{x}$ & \\
\hline Olyra latifolia $\mathrm{L}$. & $\mathrm{x}$ & \\
\hline $\begin{array}{c}\text { Oplismenopsis najada (Hack. \& } \\
\text { Arechav.) Parodi }\end{array}$ & $\mathrm{x}$ & \\
\hline Oryza sativa $\mathrm{L}$. & $\mathrm{x}$ & \\
\hline Panicum aquaticum Poir. & $\mathrm{x}$ & \\
\hline Pappophorum philippianum Parodi & $\mathrm{x}$ & \\
\hline $\begin{array}{c}\text { Parodiolyra micrantha (Kunth) } \\
\text { Davidse \& Zuloaga }\end{array}$ & $\mathrm{x}$ & \\
\hline Paspalum lepton Schult & $\mathrm{x}$ & \\
\hline Paspalum notatum Flüggé & $\mathrm{x}$ & \\
\hline $\begin{array}{l}\text { Paspalum pauciciliatum (Parodi) } \\
\text { Herter }\end{array}$ & $\mathrm{x}$ & $\mathrm{x}$ \\
\hline Paspalum plicatulum Michx. & $\mathrm{x}$ & \\
\hline Paspalum urvillei Steud. & $\mathrm{x}$ & \\
\hline Phalaris angusta Nees ex Trin. & $\mathrm{x}$ & \\
\hline Pharus lappulaceus Aubl. & $\mathrm{x}$ & $\mathrm{x}$ \\
\hline $\begin{array}{l}\text { Piptochaetium montevidense } \\
\text { (Spreng.) Parodi Rupr. }\end{array}$ & $\mathrm{x}$ & \\
\hline Poa annua L. & $\mathrm{x}$ & \\
\hline Poa bonariensis (Lam.) Kunth & $\mathrm{x}$ & \\
\hline Polypogon elongatus Kunth & $\mathrm{x}$ & \\
\hline Sacciolepis indica (L.) Chase & $\mathrm{x}$ & \\
\hline $\begin{array}{l}\text { Schizachyrium microstachyum } \\
\text { (Desv. ex Ham.) Roseng. }\end{array}$ & $\mathrm{x}$ & \\
\hline Secale cereale $\mathrm{L}$ & $\mathrm{x}$ & \\
\hline Setaria parviflora (Poir.) Kerguélen & $\mathrm{x}$ & \\
\hline Sorghastrum cf.nutans (L.) Nash & $\mathrm{x}$ & \\
\hline Spartina ciliata Brongn & $\mathrm{x}$ & \\
\hline Sporobolus indicus (L.) R.Br. & $\mathrm{x}$ & \\
\hline Steinchisma hians (Elliott) Nash & $\mathrm{x}$ & \\
\hline Stipa setigera J.Presl & $\mathrm{x}$ & \\
\hline $\begin{array}{c}\text { Streptochaeta spicata Schrad. ex } \\
\text { Nees }\end{array}$ & $\mathrm{x}$ & \\
\hline $\begin{array}{l}\text { Trachypogon filifolius (Hack.) } \\
\text { Hitchc. }\end{array}$ & $\mathrm{x}$ & \\
\hline $\begin{array}{c}\text { Tridens brasiliensis (Nees ex Steud.) } \\
\text { Parodi }\end{array}$ & $\mathrm{x}$ & \\
\hline Tripogon spicatus (Nees) Ekman & $\mathrm{x}$ & \\
\hline Triticum sp. L. & $\mathrm{x}$ & \\
\hline $\begin{array}{c}\text { Urochloa arrecta (Hack. ex } \\
\text { T.Durand \& Schinz) Morrone \& } \\
\text { Zuloaga }\end{array}$ & $\mathrm{x}$ & \\
\hline Zea mays $\mathrm{L}$. & $\mathrm{x}$ & \\
\hline $\begin{array}{l}\text { Zizaniopsis bonariensis (Balansa \& } \\
\text { Poitr.) Speg. }\end{array}$ & $\mathrm{x}$ & $\mathrm{x}$ \\
\hline
\end{tabular}

Table 1: List of 95 Poaceae species indicating monoporate and diporate apertures in the pollen grains. 


\section{Open Access Journal of Agricultural Research}

\section{Fossil Pollen Grains}

Sedimentary material previously analyzed by Bauermann (2003) [53] was selected. The sedimentary material is from Águas Claras region and the sediment has $2,70 \mathrm{~m}$ depth and $10.975 \mathrm{C}^{14} \mathrm{AP}$ of basal age. This sediment was selected for having demonstrated the registration of the whole Holocene and the presence of Poaceae pollen grains is confirmed (Bauermann 2003) [53]. The samples were chemically processed according to the methodology proposed by Faegri and Iversen (1989) [54] and the slides created using glycerinated jelly were deposited in the Laboratório de Palinologia da ULBRA. 60 Poaceae pollen grains were measured $[16,18]$ at intervals of $10 \mathrm{~cm}$, except in the samples with low frequency of Poaceae. In this case, pollen grains were measured until the number of measurements showed stability curve (Figure 2). Pollen grains with diporate aperture were observed and the diameters of the pollen grains, pores and annulus were measured.

\section{Statistical Analysis}

From the measurement data of the modern pollen grains the chart Box Plot were created in the Bioestat 5.0 software. The pollen percentage diagram was constructed by applying the information of pollen grains to the Microsoft Excel 2007 program.

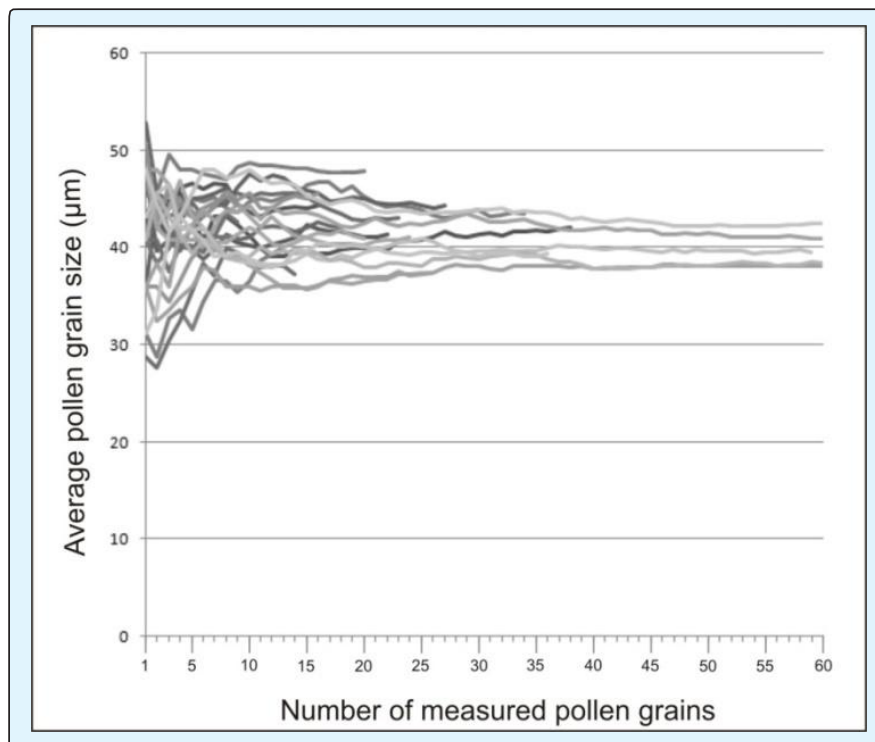

Figure 2: Stability chart of the variation of pollen grains size of the samples in relation to the number of pollen grains measured.

\section{Results}

\section{Modern Diporate Poaceae Pollen Grains}

Six species presented diporate aperture among the modern pollen grains of the 95 species analyzed for the aperture. These six species with diporate aperture have their pollen description presented along with information on vegetation type, habit, photosynthesis and life cycle according to Boldrini et al. (2008) [55] and Boldrini and Longhi-Wagner (2011) [56]. The pollen descriptions are presented in order of evolution according to Soreng et al. (2015) [57].

\section{Subfamily: Pharoideae \\ Tribe: Phareae \\ Pharus lappulaceus Aubl.}

(Figure 3A-D)

Pollen data: Monad, small and medium pollen grain, radial symmetry, heteropolar, circular amb, spheroidal, monoporate and diporate, circular pore $(3 \mu \mathrm{m})$ with annulus located in the distal pole, annulus $(8 \mu \mathrm{m})$ with 2,5 $\mu \mathrm{m}$ of thickness and ornamentation on the surface, tectate exine with columellae and microequinate ornamentation. Sexine with $0,54 \mu \mathrm{m}$ and nexine of the same thickness. D: $25 \mu \mathrm{m}$ (23-27); Ex: 1,08 $\mu \mathrm{m}$.

Botanical informations: Forest specie, herbaceous habit, C3 metabolism, estival life cycle.

\section{Subfamily: Oryzoideae \\ Tribe: Oryzeae \\ Zizaniopsis bonariensis (Balansa \& Poitr.) Speg.}

(Figure 3E-H)

Pollen data: Monad, medium pollen grain, radial symmetry, heteropolar, circular amb, spheroidal, monoporate and diporate, circular pore $(4 \mu \mathrm{m})$ with annulus located in the distal pole, annulus $(12 \mu \mathrm{m})$ with 4 $\mu \mathrm{m}$ of thickness and ornamentation on the surface, tectate exine with columellae and microequinate ornamentation. Sexine with $0,5 \mu \mathrm{m}$ and nexine of the same thickness. D: $45 \mu \mathrm{m}$ (42-48); Ex: $1 \mu \mathrm{m}$.

Botanical informations: Wetland specie, herbaceous habit, C3 metabolism, estival life cycle.

\section{Subfamily: Panicoideae \\ Tribe: Paniceae \\ Dichanthelium sabulorum (Lam.) Gould \& C.A. Clark var. sabulorum}

(Figure 3I-L)
Radaeski JN, et al. Diporate Pollen Grains of Poaceae Species: High Pollen Resolution for Reconstruction of Grasslands Vegetation. J Agri Res 2017, 2(3): 000135.
Copyright@ Radaeski JN, et al. 


\section{Open Access Journal of Agricultural Research}

Pollen data: Monad, medium pollen grain, radial symmetry, heteropolar, circular amb, spheroidal, monoporate and diporate, circular pore $(3 \mu \mathrm{m})$ with annulus located in the distal pole, annulus $(9 \mu \mathrm{m})$ with 3 $\mu \mathrm{m}$ of thickness and ornamentation on the surface, tectate exine with columellae and microequinate ornamentation. Sexine with $0,52 \mu \mathrm{m}$ and nexine of the same thickness. D: $34 \mu \mathrm{m}$ (28-39); Ex: 1,04 $\mu \mathrm{m}$.

Botanical informations: Grassland specie, herbaceous habit, C3 metabolism, estival life cycle.

Digitaria ciliares (Retz.) Koeler

(Figure 3M-P)

Pollen data: Monad, medium pollen grain, radial symmetry, heteropolar, circular amb, spheroidal, monoporate and diporate, circular pore $(3 \mu \mathrm{m})$ with annulus located in the distal pole, annulus $(9 \mu \mathrm{m})$ with 3 $\mu \mathrm{m}$ of thickness and ornamentation on the surface, tectate exine with columellae and microequinate ornamentation. Sexine with $0,52 \mu \mathrm{m}$ and nexine of the same thickness. D: $37 \mu \mathrm{m}$ (34-40); Ex: 1,04 $\mu \mathrm{m}$.

Botanical informations: Grassland specie, herbaceous habit, C4 metabolism, estival life cycle.

Echinochloa polystachya (Kunth) Hitchc.

(Figure 3Q-T)

Pollen data: Monad, medium pollen grain, radial symmetry, heteropolar, circular amb, spheroidal, monoporate and diporate, circular pore $(3 \mu \mathrm{m})$ with annulus located in the distal pole, annulus $(9 \mu \mathrm{m})$ with 3 $\mu \mathrm{m}$ of thickness and ornamentation on the surface, tectate exine with columellae and microequinate ornamentation. Sexine with $0,5 \mu \mathrm{m}$ and nexine of the same thickness. D: $40 \mu \mathrm{m}$ (35-44); Ex: $1 \mu \mathrm{m}$.

Botanical informations: Grassland specie, herbaceous habit, C4 metabolism, estival life cycle.

\section{Tribe: Paspaleae}

Paspalum pauciciliatum (Parodi) Herter

(Figure 3U-X)

Pollen data: Monad, medium pollen grain, radial symmetry, heteropolar, circular amb, spheroidal, monoporate and diporate, circular pore $(3 \mu \mathrm{m})$ with annulus located in the distal pole, annulus $(8 \mu \mathrm{m})$ with 2,5 $\mu \mathrm{m}$ of thickness and ornamentation on the surface, tectate exine with columellae and microequinate ornamentation. Sexine with $0,52 \mu \mathrm{m}$ and nexine of the same thickness. D: $42 \mu \mathrm{m}$ (37-46); Ex: 1,04 $\mu \mathrm{m}$.

Botanical informations: Grassland specie, herbaceous habit, C4 metabolism, estival life cycle.

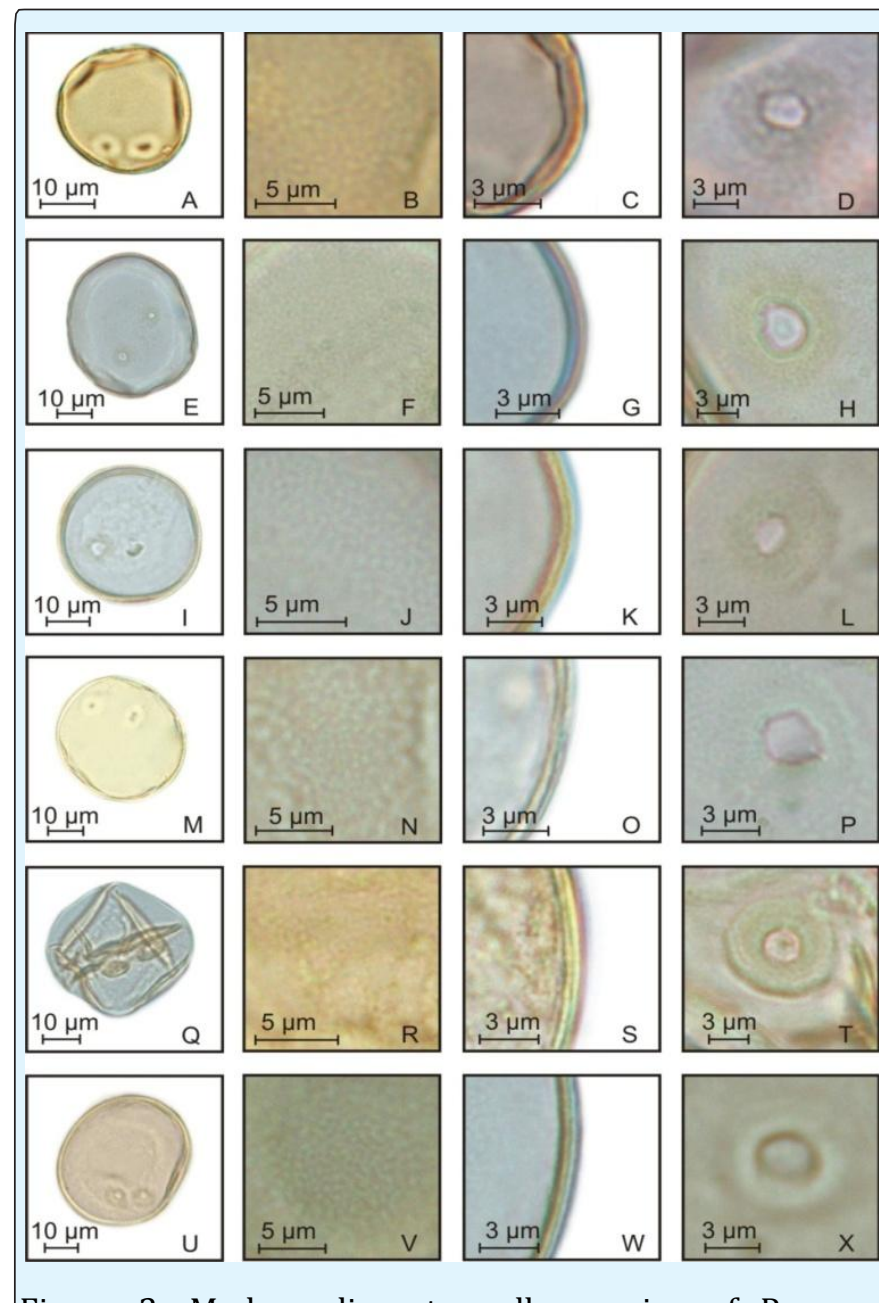

Figure 3: Modern diporate pollen grains of Poaceae species of the Rio Grande do Sul. Diporate pollen grain (A), detail of ornamentation (B), detail of exine (C) and detail of pore (D) of the Pharus lappulaceus; Diporate pollen grain $(E)$, detail of ornamentation $(F)$, detail of exine $(\mathrm{G})$ and detail of pore $(\mathrm{H})$ of the Zizaniopsis bonariensis; Diporate pollen grain (I), detail of ornamentation $(\mathrm{J})$, detail of exine $(\mathrm{K})$ and detail of pore (L) of the Dichanthelium sabulorum var. sabulorum; Diporate pollen grain $(M)$, detail of ornamentation $(N)$, detail of exine (0) and detail of pore (P) of the Digitaria ciliares; Diporate pollen grain (Q), detail of ornamentation $(\mathrm{R})$, detail of exine $(\mathrm{S})$ and detail of pore $(\mathrm{T})$ of the Echinochloa polystachya; Diporate pollen grain (U), detail 


\section{Open Access Journal of Agricultural Research}

of ornamentation (V), detail of exine (W) and detail of pore $(\mathrm{X})$ of the Paspalum pauciciliatum.

All Poaceae species with diporate pollen grains have herbaceous habit and estival life cycle. Only Pharus lappulaceus is forest specie and Zizaniopsis bonariensis is wetland specie, the others species are from grasslands. The smaller size of the pollen grains of Pharus lappulaceus indicates which palynomorphs are of herbaceous forest species. On the other hand, the larger size of the pollen grains of Zizaniopsis bonariensis Indicates occurrence of wetlands, while pollen grain sizes between 28-41 $\mu \mathrm{m}$ indicate grassland vegetation (Figure 4).

The exact distinction of pollen grains from $\mathrm{C} 3$ and $\mathrm{C} 4$ metabolism was not possible. The data showed that C3 species have a larger amplitude range of pollen size than C4 species and that the limits of size variation of C3 species can be used as markers of metabolism type.

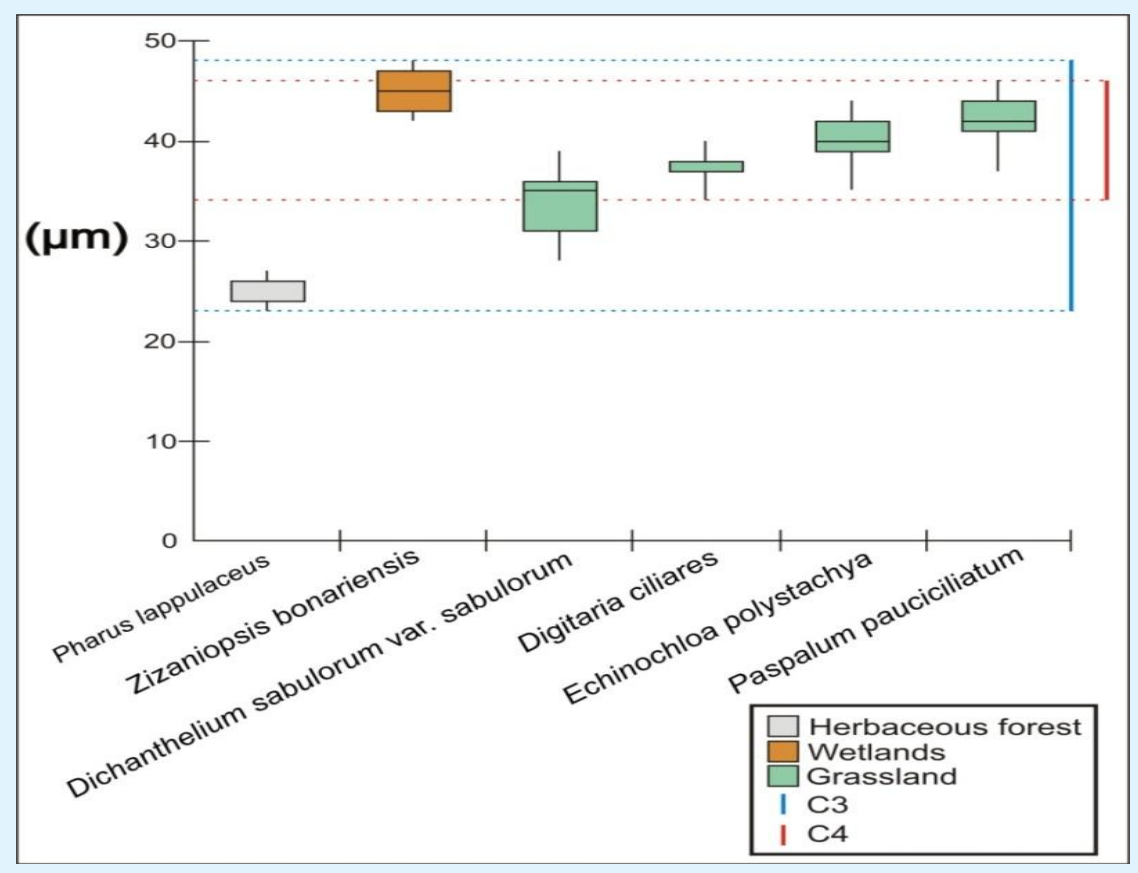

Figure 4: Chart box plot of the diameters of pollen grains of Poaceae species with diporate pollen in Rio Grande do Sul. The bold horizontal line within the box represents the median. The box shows $50 \%$ of the interquartile range, and whiskers the total variation.

\section{Fossil Diporate Poaceae Pollen Grains}

Seven fóssil diporate pollen grains of Poaceae species were found (Figure 5) in the all the sediment. The pollen grains were found in recent ages related to the Late Holocene (3.420 years BP to the present). The samples showed absence of diporate Poaceae pollen grains in the lower portion of the profile between the depths 0,95-2,70 $\mathrm{m}$ (Table 2). There is an increase in the concentration of diporate pollen grains at more recent ages (from 1.340 years BP to the present). Some pollen grains could be identified at the specie level (Dichantelium sabulorum var. sabulorum) and others indicated the type of environment (five pollen grains are from the grassland vegetation) and the type of photosynthesis (three pollen grains are from species with C3 metabolism). Diporate pollen grains from forest vegetation were not found. Two pollen grains could not be identified beyond the family level because their sizes are similar to the grassland and wetland species (Figure 6).

\begin{tabular}{|c|c|c|c|c|}
\hline Depth & Pollen grain size & Vegetation & Metabolism & Pollen type \\
\hline $0,05 \mathrm{~m}$ & $28,8 \mu \mathrm{m}$ & Grassland & $\mathrm{C} 3$ & Dichantelium sabulorum \\
\hline $0,05 \mathrm{~m}$ & $31,2 \mu \mathrm{m}$ & Grassland & $\mathrm{C} 3$ & Dichantelium sabulorum \\
\hline $0,05 \mathrm{~m}$ & $43,2 \mu \mathrm{m}$ & Grassland/Wetland & $\mathrm{C} 3 / \mathrm{C} 4$ & Poaceae \\
\hline
\end{tabular}




\section{Open Access Journal of Agricultural Research}

\begin{tabular}{|c|c|c|c|c|}
\hline $0,15 \mathrm{~m}$ & $43,2 \mu \mathrm{m}$ & Grassland/Wetland & C3/C4 & Poaceae \\
\hline $0,35 \mathrm{~m}$ & $36 \mu \mathrm{m}$ & Grassland & C3/C4 & Grassland \\
\hline $0,65 \mathrm{~m}$ & $36 \mu \mathrm{m}$ & Grassland & C3/C4 & Grassland \\
\hline $0,85 \mathrm{~m}$ & $33,6 \mu \mathrm{m}$ & Grassland & $\mathrm{C} 3$ & Dichantelium sabulorum \\
\hline
\end{tabular}

Table 2: Information on the depths and ages of the samples where diporate Poaceae pollen grains were found.
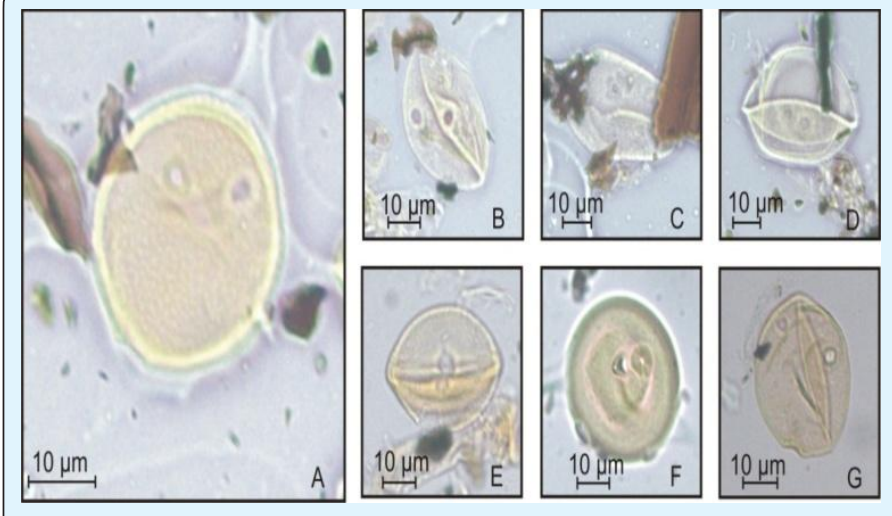

Figure 5: Fossil diporate Poaceae pollen grains from the sediment of Águas Claras region, Rio Grande do Sul.

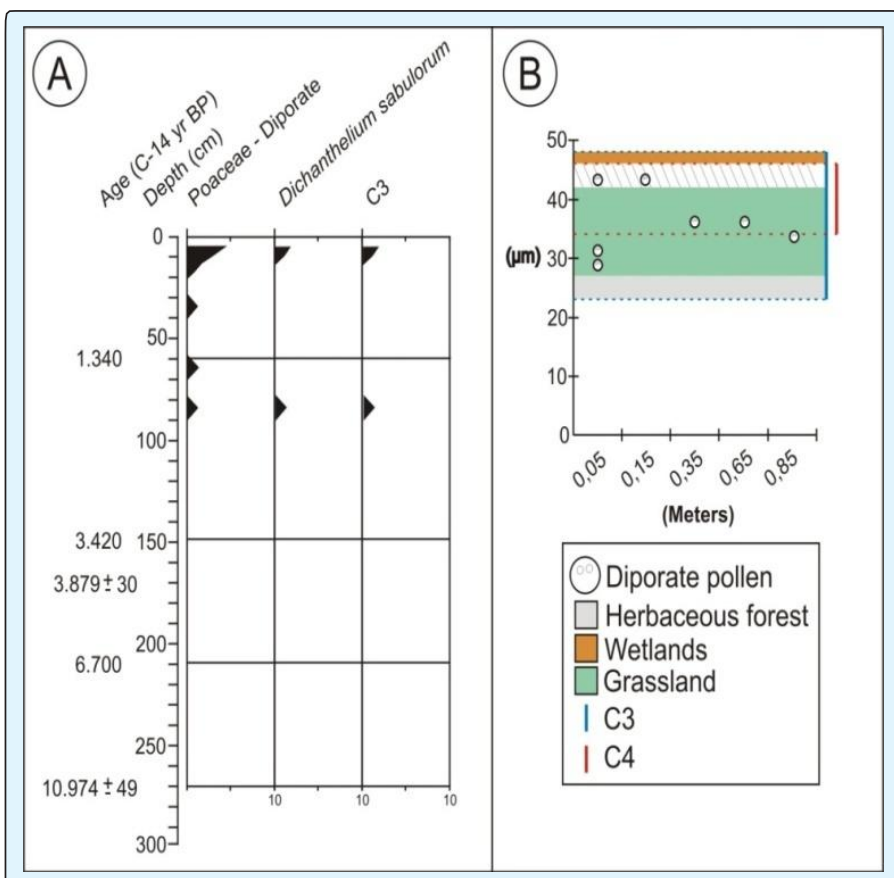

Figure 6: Pollen percentage diagram of Poaceae diporate pollen grains showing the ages and depths in which they were recorded in the profile of Águas Claras region (A). Chart of the sizes of the fossil diporate pollen grains together with the ecological information obtained by modern pollen grains (B). " $\backslash \backslash$ ”"Overlap between pollen grain sizes of grassland and wetland species.

\section{Discussion}

Diporate pollen grains from Poaceae species had not been recorded in South America Quaternary sediments. On the other hand, some modern diporate pollen grains have been described for several regions of the world, including South America [5, 6, 30].

Some species of the genus Agrostis, Bromus, Calamagrostis, Chusquea and Melinis showed diporate aperture in the pollen grains described in Venezuela [5]. However, the species of these genera that we analyzed showed pollen grains with only one aperture. The diporate aperture found in Pharus lappulaceus in Southern Brazil was not shown in the same species described in Venezuela [5]. However, the size variation of the pollen grains of this specie in the present work is similar to the sizes described for Venezuela and São Paulo - Brazil [5,30]. Dichanthelium sabulorum was analyzed by Côrrea et al. (2005) [30] and showed pollen grain size similar to the present study, but the type of diporate aperture that we find in the southern Brazilian specie is not described for the specimen of São Paulo.

The species Cenchrus brownii, Digitaria ciliares, Ischaemum rugosum, Paspalum conjugatum and Sporobolus indicus described by Roubik \& Moreno (1991) [6] showed diporate pollen grains. In our study, Digitaria ciliares also demonstrated diporate aperture although the size of the pollen grain that we observed is smaller than the size of pollen described in Barro Colorado. Furthermore, Sporobolus indicus showed only monoporate aperture in the specimen of Rio Grande do Sul. Pollen grains of some species of Paspalum genus, including Paspalum urvillei, showed diporate aperture according to Zucol (1998) [48]. However, diporate pollen grains were not observed in Paspalum urvillei that we analyze.

\section{Paleoecological Implications}

According to Bauermann (2003) [53] in the Águas Claras region, forest vegetation existed in higher distribution that Grassland vegetation in the period of 3.420-1.340 BP. In our analysis of pollen grains from the 


\section{Open Access Journal of Agricultural Research}

profile showed that Pharus lappulaceus (herbaceous forest specie) not lived in this vegetation. In this period, the record of species of the Atlantic Forest indicates occurrence of warm and humid climate conditions [53]. The pollen of C3 Poaceae that we have identified for this period confirms for the occurrence of humid climate.

The forest vegetation also expanded on the grasslands in the period between $1.340 \mathrm{BP}$ to the present indicating that the Restinga forest occurred in mosaic with the grassland vegetation established in the drier areas [53]. The grassland vegetation that occurred in mosaic is confirmed by the diporate Poaceae pollen grains. These diporate pollen grains indicate the occurrence of grassland vegetation even though the forest vegetation has dominated. Dichanthelium sabulorum probably was part of this grassland vegetation since $2.000 \mathrm{BP}$. This species lives in open formations, in the natural grasslands generally forming rosetted clumps $[55,56]$. The increase of diporate pollen of C3 grasses in this period also reinforces that humid climate occurred as the current climate as verified by Bauermann (2003) [53].

\section{Conclusion}

The current vegetation of the Águas Claras region has C3 and C4 Poaceae species living together. The record of diporate pollen grains $\mathrm{C} 3$ and $\mathrm{C} 4$ evidences this vegetative distribution since the Late Holocene (1.340 years BP). C3 diporate Poaceae species that reflect the occurrence of humid climate have increased the concentration since 2.000 years BP. This increase is probably related to the greater humidity in the Coastal Plain of Rio Grande do Sul and in several other regions of the State where the Campos replaced by the forests in this period. Diporate pollen grains of wetlands/grasslands were found at more recent ages of the profile indicating that the humidity increased progressively until the current climate in the region of Águas Claras.

Modern diporate pollen grains of six species of the dataset (95 Poaceae species analyzed for aperture) allowed higher pollen taxonomic resolution. Statistical tests applied to modern pollen grains indicated potential information for use in fossil records. Pollen types for ecological inferences could be characterized from the differences in pollen grain sizes among forest, grassland and wetland species.

The quaternary sediment analyzed records the entire Holocene. However, the seven fossil diporate pollen grains identified were present only in samples that reflect the Late Holocene. Three of the seven pollen grains were identified at the species level, also indicate the type of photosynthesis. Furthermore, two pollen grains suggest the type of vegetation. The integration of modern-fossil pollen data was shown to be appropriate to increase pollen refinement in the Poaceae family. Despite the low preservation of diporate pollen grains, this study provides important information to obtain pollen taxonomic resolution of Poaceae species. The data obtained by this high pollen taxonomic resolution increase paleoecological inferences about the dynamics of vegetation in the past.

\section{Acknowledgments}

Our appreciation goes to Dr. Angelo Alberto Schneider from UNIPAMPA, for the great help with the identification of botanical materials.

\section{References}

1. Erdtman G (1952) Pollen morphology and plant taxonomy. Angiosperms. Stockholm, Almkvist \& Wiksell. Science 117(3030): 86-87.

2. Salgado-Labouriau ML (1973) Contribuição à palinologia dos cerrados. Rio de janeiro: Academia Brasileira de Ciências: 291.

3. Heusser CJ (1971) Pollen and spores of Chile. The university of Arizona Press, Tucson.

4. Markgraf V, D'Antoni H (1978) Pollen flora of Argentina. Tucson, University of Arizona Press.

5. Salgado-Labouriau ML, Rinaldi M (1990) Palynology of Gramineae of the Venezuelan Mountains. Grana 29(2): 119-128.

6. Roubik DW, Moreno JE (1991) Pollen and Spores of Barro Colorado Island.St. Louis, Missouri Botanical Garden 36.

7. Katsiotis A, Forsberg RA (1995) Pollen grain size in four ploidy levels of genusAvena. Euphytica 83(2): 103-108.

8. Tedesco SB, Battistin A, Valls JFM (1999) Diâmetro dos grãos de pólen e tamanho dos estômatos em acessos diplóides e tetraplóides de Hemarthria altissima (Poiret) Stapf \& Hubbard (Gramineae). Santa Maria. Ciência Rural 29(2): 273-276. 


\section{Open Access Journal of Agricultural Research}

9. Melhem TS, Cruz-Barros MAV, Corrêa MAS, MakinoWatanabe H, Silvestre-Capelato MSF, et al. (2003) Variabilidade polínica em plantas de Campos do Jordão (São Paulo, Brasil). Boletim Instituto de Botânica 16: 16-104.

10. Wilberger TP, Stranz A, Paz C, Boeni B, Cancelli RR, et al. (2004) Flora do Setor Oriental do Planalto sul-riograndense. Guia de espécies vegetais. 1aㅡ ed., São Leopoldo, ALPP.

11. Joly C, Barillé L, Barreau M, Mancheron A, Visset L (2007) Grain and annulus diameter as criteria for distinguishing pollen grains of cereals from wild grasses. Review of Palaeobotany and Palynology 146(1-4): 221-233.

12. Medeanic S, Cordazzo CV, Lima LG (2008) Diversidade Polínica de Plantas em Dunas no Extremo Sul do Brasil. Porto Alegre, Gravel 6(1): 67-80.

13. Nakamura AT, Longhi-Wagner HM, Scatena VL (2010) Anther and pollen development in some species of Poaceae (Poales). Braz J Biol 70(2): 351-360.

14. Radaeski JN, Evaldt ACP, Lima GL, Bauermann SG (2011) Grãos de pólen das formações campestres sulbrasileiras. Canoas, Revista de Iniciação Científica da ULBRA 9: 59-67.

15. Schüler L, Behling $H$ (2011a) Characteristics of Poaceae pollen grains as a tool to assess palaeoecological grassland dynamics in South America. Veget Hist Archaeobot 20.

16. Schüler L, Behling H (2011b) Poaceae pollen grain size as a tool to distinguish past grasslands in South America: a new methodological approach. Veget Hist Archaeobot 20(2): 83-96.

17. Bauermann SG, Radaeski JN, Evaldt ACP, Queiroz EP, Mourelle D, et al. (2013) Pólen nas angiospermas: diversidade e evolução. Canoas, Editora da ULBRA.

18. Jan F, Schüler L, Behling H (2014) Trends of pollen grain size variation in C3 and C4 Poaceae species using pollen morphology for future assessment of grassland ecosystem dynamics. Grana 53: 1-17.

19. Radaeski JN, Evaldt ACP, Bauermann SG (2014a) Grãos de pólen de espécies ocorrentes na Unidade de Conservação Parque Estadual do Espinilho, Barra do Quarai, Rio Grande do Sul, Brasil. Pesquisas, Botânica 65: 305-331.
20. Radaeski JN, Evaldt ACP, Bauermann SG, Lima GL (2014b) Diversidade de grãos de pólen e esporos dos Campos do sul do Brasil: descrições morfológicas e implicações paleoecológicas. Porto Alegre, IHERINGIA, Série Botânica 69(1): 107-132.

21. Radaeski JN, Bauermann SG, Pereira AB (2016) Poaceae Pollen from Southern Brazil: Distinguishing Grasslands (Campos) from Forests by Analyzing a Diverse Range of Poaceae Species. Frontiers in Plant Science 7: 1833.

22. Köhler E, Lange E (1979) A contribution to distinguishing cereal from wild grass pollen grains by LM and SEM. Grana 18(3): 133-140.

23. Chaturvedi M, Yunus D, Datta K (1994) Pollen morphology of Sorghum Moench-Sections Eu-sorghum and Para-sorghum. Grana 33(3): 117123.

24. Linder HP, Ferguson IK (1985) On the pollen morphology and phylogeny of the Restionales and Poales. Grana 24(2): 65-76.

25. Chaturvedi M., Datta, K, Nair PKK (1998) Pollen morphology of Oryza (Poaceae). Grana 37(2): 79-86.

26. Chaturvedi M, Datta K (2001) Pollen morphology in Saccharurn L. (Poaceae) - wild and cultivated sugar cane species. Feddes Repertorium 112(5-6): 387-390.

27. Skvarla JJ, Rowley JR, Hollowell VC, Chissoe WF (2003) Annulus-Pore relationship in Gramineae (Poaceae) pollen: the pore margin of Pariana. Am J Bot 90(6): 924-930.

28. Datta K, Chaturvedi M (2004) Pollen morphology of Basmati cultivars (Oryza sativa race Indica) - exine surface ultrastructure. Grana 43(2): 89-93.

29. Liu Q, Zhao N, Hao G (2004) Pollen morphology of the Chloridoideae (Gramineae). Grana 43: 238-248.

30. Côrrea AMS, Guimarães MITM, Cruz-Barros MAV, Begale FF (2005) Flora polínica da Reserva do Parque Estadual das Fontes do Ipiranga (São Paulo, Brasil). Hoehnea 32: 269-282.

31. Liu Q, Zhao N, Hao G (2005) Pollen morphology of Eustachys tenera (Chloridoideae, Gramineae). Pak J Bot 37(3): 503-506. 


\section{Open Access Journal of Agricultural Research}

32. Perveen A (2006) A Contribution to the Pollen Morphology of Family Gramineae. World Applied Sciences Journal 1(2): 60-65.

33. Kashikar N, Kalkar SA (2010) Pollen morphology of millets-exine surface ultrastructure. Asian J Exp Biol Sci Spl 85-90.

34. Ahmad FA, Khan MA, Ahmad M, Zafar M, Khan A, et al. (2011) Palynological studies in tribe Chlorideae (Poaceae) from salt range of Pakistan. African Journal of Biotechnology 10(44): 8909-8913.

35. Dórea MC (2011) Morfologia polínica, fenologia reprodutiva e biologia floral de espécies florestais de Poaceae. Ph.D. Thesis, Universidade Estadual de Feira de Santana.

36. Perveen A, Qaiser M (2012) Pollen flora of Pakistan LXIX. Poaceae. Pak J Bot 44(2): 747-756.

37. Mander L, Li M, Mio W, Fowlkes CC, Punyasena SW (2013) Classification of grass pollen through the quantitative analysis of surface ornamentation and texture. Proceedings of the Royal Society, Biological Sciences 280(1770): 1-7.

38. Nazir A, Khan MA, Abbasi AM, Zahidullah (2013) Palynological Studies in Tribe Aveneae (Poaceae) from Potohar of Pakistan. International Journal of Sciences: Basic and Applied Research 10(1): 120-125.

39. Mander L, Baker SJ, Belcher CM, Haselhorst DS, Rodriguez J, et al. (2014) Accuracy and consistency of grass pollen identification by human analysts using electron micrographs of surface ornamentation. Appl Plant Sci 2(8): 1-11.

40. Mander L, Punyasena SW (2015) Grass pollen surface ornamentation: a review of morphotypes and taxonomic utility. Journal of Micropalaeontology 35(2): 121-124.

41. Morgado LN, Gonçalves-Esteves V, Resendes R, Ventura MAM (2015) Pollen morphology of Poaceae (Poales) in the Azores, Portugal. Grana 54(4): 282293.

42. Needham I, Vorontsova MS, Banks H, Rudall PJ (2015) Pollen of Malagasy grasses as a potential tool for interpreting grassland palaeohistory. Grana 54(4): 247-262.
43. Silva CI, Fonseca VLI, Groppo M, Bauermann SG, Saraiva AM, et al. (2014) Catálogopolínico das plantasusadasporabelhas no Campus da USP de RibeirãoPreto. Ribeirão Preto, SP: Holos: 153.

44. Rede de catálogos polínicos online. disponível em: < http://chaves.rcpol.org.br/ >. acesso em: 24/01/2017.

45. Guohua MA, Xuelin H, Qiusheng X, Bunn E (2009) Multiporate pollen and apomixes in Panicoideae. Pak J Bot 41(5): 2073-2082.

46. Radaeski JN (2015) Morfologia polínica de táxons de Poaceae do Rio Grande do Sul: uma abordagem para distinguir vegetações campestres e florestais no sul do Brasil. Dissertação (Mestrado em Ciências Biológicas) - Universidade Federal do Pampa, São Gabriel: 85.

47. Erdtman G (1944) Pollen morphology and plant taxonomy II: Notes on some monocotyledonous pollen types. Svensk Botaniska Tidskrift 38: 163-168.

48. Zucol AF (1998) Granos de polen anómalos em Paspalum unispicatum, $P$. decumbens y $P$. urvillei (Poaceae, Paniceae). Darwiniana 36(1-4): 95-100.

49. Ma GH, Zhao NX, Hu XY (2001) Pollen morphology and poly-aperture in Paspalum. J Trop Subtrop Bot 9(3): 201-204.

50. Erdtman G (1952) Pollen Morphology and Plant Taxonomy. Angiosperms. Stockholm: Almkvist \& Wiksell.

51. Barth OM, Melhem TS (1988) Glossário Ilustrado de Palinologia. Campinas, Editora da UNICAMP.

52. Punt $\mathrm{W}$, Hoen PP, Blackmore $\mathrm{S}$, Nilsson $\mathrm{S}$, Le Thomas A (2007) Glossary of pollen and spore terminology. Review of Palaeobotany and Palynology 143(1-2): 181.

53. Bauermann SG (2003) Análises palinológicas e evolução paleovegetacional e paleoambiental das turfeiras de Barrocadas e Águas Claras, Planície Costeira do Rio Grande do Sul, Brasil. Ph.D. Thesis, Universidade Federal do Rio Grande do Sul, Porto Alegre 137.

54. Faegri K, Iversen J (1989) Textbook of Pollen Analysis. New York, John Wiley \& Sons, 328. 


\section{Open Access Journal of Agricultural Research}

55. Boldrini II, Longhi-Wagner HM, Boechat SC (2008) Morfologia e taxonomia de gramíneas sul-riograndenses. $2^{\text {nd }}(E d n$.$) Porto Alegre: Editora UFRGS$ 87.

56. Boldrini II, Longhi-Wagner, HM (2011) Poaceae no Rio Grande do Sul: Diversidade, Importância na Fitofisionomia e Conservação. Ciência \& Ambiente 42: 71-92.

57. Soreng RJ, Peterson PM, Romaschenko K, Davidse G, Zuloaga FO, et al. (2015) A worldwide phylogenetic classification of the Poaceae (Gramineae). Journal of Systematics and Evolution 53(2): 117-137. 